\title{
Considering milk price volatility for investment decisions on the farm level after European milk quota abolition
}

\author{
H. D. Schulte, ${ }^{* 1}$ O. Musshoff, ${ }^{*}$ and M. P. M. Meuwissen† \\ *Department of Agricultural Economics and Rural Development, Georg-August-Universität Göttingen, 37073 Göttingen, Germany \\ †Business Economics Group, Department of Social Sciences, Wageningen University and Research, $6706 \mathrm{KN}$, Wageningen, the Netherlands
}

\begin{abstract}
After the abolition of the milk quota in the European Union, milk price volatility is expected to increase because of the liberalized market conditions. At the same time, investment appraisal methods have not been updated to capture the increased uncertainty. Therefore, the objective of this paper is to assess the effect of changing price volatility due to quota abolition on investment decisions at the dairy farm level. To contribute to the objective and to approximate milk price volatility after the European milk quota abolition, the risk-adjusted discount rate for risk-averse dairy farmers is derived based on the milk price volatility of a milk price series from New Zealand. New Zealand dairy farmers have faced liberalized market conditions for more than 3 decades. Afterward, the risk-adjusted discount rate is applied to appraise milking technology investments for an average German dairy farmer. The results show that it is still more reasonable to invest in a parlor system than an automated milking system, although the net present value of the parlor system investment varies between $€ 191,723$ for risk-neutral dairy farmers and €100,094 for modestly risk-averse dairy farmers. For the automated milking system investment, the same calculations lead to $€ 132,702$ for risk-neutral dairy farmers and $€ 31,635$ for risk-averse dairy farmers. According to higher levels of milk price volatility after milk quota abolition, the reduction of the expected utility of the underlying investment decision for modest risk-averse dairy farmers is almost similar to a milk price decrease of $5 \%$ for risk-neutral dairy farmers. Therefore, the findings urge finance providers and extension services to consider the change of increasing milk price volatility after dairy quota abolition when giving dairy farmers financial advice. The risk-adjusted discount rate is a flexible tool to do so.
\end{abstract}

Received December 17, 2017.

Accepted April 22, 2018.

${ }^{1}$ Corresponding author: hinrich.schulte@agr.uni-goettingen.de
Key words: milk quota abolition, risk-adjusted discount rate, investment decision, risk aversion

\section{INTRODUCTION}

In April 2015, the European Union (EU) abolished the milk quota regimen, thus enabling European dairy markets to increasingly connect to world markets (Jongeneel et al., 2010). Consequently, spillover effects from energy markets and horizontal transmissions of milk price volatility from international markets might increase milk price volatility in the EU after milk quota abolition (Jongeneel et al., 2010; Fousekis et al., 2017). Focusing on the farm level, a high share of dairy farmers is concerned about the dairy quota abolition, and they perceive milk price volatility as a greater risk after quota abolition (Scharner et al., 2016; Assefa et al., 2017).

Most of the decision makers in agricultural production are thought to be risk averse (Maart-Noelck and Musshoff, 2014). Risk-averse farmers, faced with increased milk price volatility, can be expected to pay a specific amount of money to eliminate exposure to this risk (El Benni and Finger, 2013). These are costs of risk, known as the risk premium, which we can approximate (Kim and Chavas, 2003; Hardaker et al., 2004, p. 101). Focusing on milk price volatility, the risk premium is dependent on the level of milk price volatility and the risk attitude of a decision maker (Di Falco and Chavas, 2006; El Benni and Finger, 2013). Nevertheless, investment appraisal studies in the dairy sector have barely considered the risk premium; rather, they have assumed a constant milk price (Purvis et al., 1995; Dijkhuizen et al., 1997), carried out sensitivity analyses of milk prices (Shortall et al., 2016), or simulated different levels of milk prices (Hyde et al., 2003). Thus, they referred to different levels of milk prices but did not account for the costs of risk regarding milk price volatility.

To account for investment risks on the dairy farm level, Tauer (2002) estimated risk-adjusted discount rates (RADR) for risk-averse dairy farmers by econometric analyses. Subsequently, Tauer (2006) used these 
RADR for analyzing implications of entrepreneurial flexibility. However, estimating the RADR based on the econometric approach of Tauer (2002), it might become difficult to adjust the RADR if price volatility changes because its dependence on risk attitude is not obvious. To overcome this, expected utility approaches are a valuable alternative to calculate the RADR for riskaverse decision makers (Finger, 2016) because these better describe the relationship between the level of milk price volatility and the risk attitude of the decision maker. In this context, the objective of this paper is to assess the effect of changing milk price volatility on investment decisions of risk-averse dairy farmers after milk quota abolition.

To approximate milk price volatility after quota abolition, we used a farm-gate milk price series from New Zealand (NZ). New Zealand has liberalized market conditions and might strongly compete with the EU for export markets in China and Southeast Asia after milk quota abolition (Fousekis et al., 2017). Thus, the NZ data reflect milk price volatility under world market conditions, which might provide insights into EU milk price volatility after dairy quota abolition. To show the influence of milk price volatility, we measured the RADR for an investment decision between 2 milking technologies: a parlor system and an automated milking system (AMS). Thus, the novelty of the study is the approximation of milk price volatility to evaluate investment decisions after the European milk quota abolition.

\section{MATERIALS AND METHODS}

\section{Net Present Value for Investment Appraisal}

Calculation of the net present value (NPV) is a widely used investment method to maximize utility of a decision maker by choosing the investment that offers the highest net profitability (Shortall et al., 2016). One should invest when the NPV of the investment cash inflows exceeds the investment cash outflows and choose the investment with the highest NPV. The NPV is defined as follows:

$$
N P V=-I N V+\sum_{t=1}^{T}\left[\frac{N C F_{t}}{(1+i)^{t}}\right]+\frac{s a l v_{T}}{(1+i)^{T}},
$$

where $I N V$ is the cost of the investment, $N C F$ is the annual net cash flow (i.e., cash inflow minus cash outflows per period $t$ ), and $s a l v_{T}$ is the salvage value of the investment after $T$ years.

Following the objective, we focus on the milk price. The milk price is part of the annual net cash flow, and one must discount the milk price by a risk-free interest rate $i$ to address the time value. However, this implies that the decision maker is risk neutral, whereas most decision makers in agricultural production are risk averse (Gardebroek, 2006; Maart-Noelck and Musshoff, 2014). This means that the discounted value of the milk price for risk-averse dairy farmers is dependent not only on the risk-free interest rate but also on the volatility of the milk price and the level of risk aversion. To account for this, a risk-loaded component $v$ is added to the riskfree interest rate $i$. The sum of these components leads to the RADR (Finger, 2016). Thus, one can calculate the discounted price $P_{0}$ of the expected milk price $E\left(P_{t}\right)$ in $t$ as follows:

$$
P_{0}=\frac{E\left(P_{t}\right)}{(1+i+v)^{t}} .
$$

Discounting for $v \succ 0$ implies that the dairy farmer is risk averse and willing to pay a specific amount to prevent planning uncertainty. Subsequently, a certainty equivalent $(\mathrm{CE})$ of the milk price for risk-averse dairy farmers exists where a certain and lower milk price has the same discounted value as an uncertain milk price $E\left(P_{t}\right)$ :

$$
P_{0}=\frac{C E\left(P_{t}\right)}{(1+i)^{t}} .
$$

The difference between the expected milk price $E\left(P_{t}\right)$ and the $C E\left(P_{t}\right)$ of risk-averse dairy farmers is the cost of risk, denoted as $R P\left(P_{t}\right)$ (Kim and Chavas, 2003; Hardaker et al., 2004, p. 101). Following Pratt (1964), we assumed an exponential risk utility function and approximated the $R P\left(P_{t}\right)$ as follows:

$$
R P\left(P_{t}\right)=E\left(P_{t}\right)-C E\left(P_{t}\right)=0.5 \cdot r_{a} \cdot \operatorname{VAR}\left(P_{t}\right) .
$$

Subsequently, $R P\left(P_{t}\right)$ is dependent on the variance $\operatorname{VAR}\left(P_{t}\right)$ of the milk price series and the risk attitude of the decision maker, which is denoted by $r_{a}$ (i.e., constant absolute risk aversion). The variable $r_{a}$ is the quotient of the $r_{r}$, which represents constant relative risk aversion (CRRA) and the expected value of the milk price $E\left(P_{t}\right)$ (Gardebroek, 2006). Usually, the range of $r_{r}$ takes values from $r_{r}=0$, which implies risk neutrality, to $r_{r}=4$, which reflects a highly risk-averse decision maker (Hardaker et al., 2004, p. 109).

Furthermore, equating Equations 2 and 3 and having in mind the calculation of $R P\left(P_{t}\right)$ to solve for $v$ leads to the following equation: 


$$
\begin{aligned}
& v=(1+i) \cdot\left\{\left[\left(\frac{E\left(P_{t}\right)}{C E\left(P_{t}\right)}\right)^{\frac{1}{t}}\right]-1\right\}= \\
& (1+i) \cdot\left\{\left[\left(\frac{E\left(P_{t}\right)}{E\left(P_{t}\right)-R P\left(P_{t}\right)}\right)^{\frac{1}{t}}\right]-1\right\} .
\end{aligned}
$$

Because $R P\left(P_{t}\right)$ is included in Equation 5 and in Equation 4, it shows that the risk-loaded variable $v$ is dependent on the variance $\operatorname{VAR}\left(P_{t}\right)$ of the milk price series, the risk attitude $r_{a}$, and the time $t$. Hence, the value of the variable $v$ is time varying.

At first glance, the development of $v$ over time might not be intuitive. One might suggest that $v$ should increase as the time horizon increases because the variance - and hence the uncertainty - of price developments increases. In other words, it might be more difficult to predict the price in later years than in earlier years, and therefore $v$ should increase. This seems to be reasonable, but if we go back to the calculations of $v$ (referring to Equation 5), we notice that the time $t$ and the variance of the time series in Equation 5 have countervailing influences on $v$. Although the variance is increasing over time, it might not lead to an increase in $v$ because the influence of $t$ on $v$ could be much stronger and leads to a decreasing $v$ over time. Assuming a decreasing development of $v$ over time, a mathematical reason might exist, but it does not answer the question of whether it is reasonable. Therefore, we refer to hyperbolic discounting, in which similar developments of interest rates reasonably occur. Hyperbolic discounting has its roots in experimental economics, which has found that decision makers assess risks in the near future as more severe than risks in later years (Laibson, 1997; Frederick et al., 2002). Thus, the expected utility approach could lead to declining development of the RADR, which becomes reasonable if we refer to the hyperbolic discounting theory. In contrast to econometric approaches such as Tauer (2002) that assume the RADR is constant over time, the expected utility approach leads to time-adjusted RADR values.

\section{Data and the Modeling of Price Volatility}

To analyze the milk price series after dairy quota abolition, we cannot use a European milk price series because the time series is too short to determine whether any pattern of specific milk price volatility exists since the quota abolition. To approximate the change of the milk price volatility after milk quota abolition, we used a milk price series from 1999 until 2014 of a dairy processor from NZ, provided by the Dutch agricultural and horticultural organization LTO (LTO, 2016; see Supplemental File S1; https://doi.org/10.3168/jds .2017-14305). As a reference, we also used a milk price series of a German dairy processor. We corrected both milk price series for inflation and calculated price on a monthly basis from 1999 until 2014 in euro-cents per kilogram of ECM with $4.2 \%$ fat and $3.4 \%$ protein (for an overview, see Supplemental File S1; https://doi.org/ 10.3168/jds.2017-14305).

Regarding price modeling, Tauer (2006) used geometric Brownian motion, which characterizes a random walk of prices. However, price series can also contain mean reverting structures, implying that the milk price, though variable, tends to return to the mean of the price series (Dixit and Pindyck, 1994, p. 74). To classify such structures and test for stationarity, we applied an augmented Dickey-Fuller generalized least squares test (Elliott et al., 1996). We found that both milk price series were stationary and therefore denote mean reverting structures (see Supplemental Files S2 and S3; https://doi.org/10.3168/jds.2017-14305). Dixit and Pindyck (1994, p. 74) noted that mean-reverting processes are generally logical for agricultural commodities because prices of raw commodities in the long run mostly develop toward their marginal costs of production. Regarding the mean reverting process, Isik (2006) recommends the Ornstein-Uhlenbeck process (OUP) for investments in agricultural technologies. To overcome negative prices, we set $x_{t}=\log \left(P_{t}\right)$, with $P_{t}$ being milk price in period $t$, and defined the OUP as follows (Dixit and Pindyck, 1994, p. 74):

$$
d x_{t}=\eta \cdot\left(\bar{x}-x_{t-d t}\right) \cdot d t+\sigma \cdot d z_{t} .
$$

The change in logs of prices $d x$ is dependent on the speed of mean reverting $\eta$, and the level to which the price reverts is denoted as the "normal" level $\bar{x}$. Thus, the expected change in milk price depends on the difference between the normal level and the milk price observation $\left(x_{t-d t}\right)$. Furthermore, the standard deviation of the process is described by $\sigma$ and multiplied with the increment of a Wiener process $d z_{t}$. Hence, the OUP follows the Markov requirements because it does not contain any independent increments, which implies that observations in $t$ are only dependent on observations in $t-1$ (Dixit and Pindyck, 1994, p. 74).

Based on the OUP, the milk price $x_{t}$ is changing over time, the expected values for $x_{t}$ are $E\left(x_{t}\right)=x_{0} e^{-\eta t}+\bar{x} \cdot\left(1-e^{-\eta t}\right)$, and the variance of $x_{t}$ is denoted as $\operatorname{VAR}\left(x_{t}\right)=\left(1-e^{-2 \eta t}\right) \cdot \frac{\sigma^{2}}{2 \eta}$ (Dixit and Pindyck, 1994, p. 74). Subsequently, the lower the speed of 
return $\eta$, the higher the variance of the price series. Furthermore, if $t$ approaches infinity, the expected price level is $\bar{x}$ and the variance in the long run is $\operatorname{VAR}\left(x_{t}\right)=\frac{\sigma^{2}}{2 \eta}$. We calculated and estimated the values of the coefficients for both time series based on the formulas of Dixit and Pindyck (1994, pp. 76-77). The values for the NZ price series were $\bar{x}=3.22, \eta=0.06$, and $\sigma=0.08$, whereas the values for the German price series were $\bar{x}=3.40, \eta=0.06$, and $\sigma=0.04$. Following Vasicek (1977), the resulting expected values and variance for the milk price $P_{t}$ were $E\left(P_{t}\right)=e^{E\left(x_{t}\right)+0.5 \cdot \operatorname{VAR}\left(x_{t}\right)}$ and $\operatorname{VAR}\left(P_{t}\right)=e^{2 E\left(x_{t}\right)+\operatorname{VAR}\left(x_{t}\right)} \cdot\left[e^{\operatorname{VAR}\left(x_{t}\right)}-1\right]$, respectively.

\section{Variables and Parameters for Investing in Milking Technologies}

To demonstrate the influence of the RADR on investment decisions, we calculated the NPV of an AMS and parlor system investment. We show the values of the variables that determine the investment decision in Table 1, which we kept constant in the NPV calculations.

Most of the values we collected were from Steeneveld et al. (2012) because the structure of dairy farms in the Netherlands is rather comparable with German conditions. We assume that the farmer must purchase one milking system or the other and does not have the ability to wait to make a decision. Following this, flexibility is not considered and the NPV approach is adequate to assess this investment decision (Shortall et al., 2016). Furthermore, we calculated the NPV based on a herd size of 60 cows, which was the average size of German dairy farms (Statistisches Bundesamt, 2016) and the minimum number of cows needed for an AMS (Hyde et al., 2007). The milk yield is a bit higher for the AMS than for the parlor system because cows in AMS get milked more often than in parlor systems. Therefore, the feed costs, which we included in material costs, are higher for AMS than for parlor systems. Furthermore, we assumed that the basis of the milk revenues is the milk price. However, smaller changes in the milk revenue might occur because of price premiums for ingredients such as fat and protein. To account for this, we used the milk revenue for our calculations. In contrast, using the average milk price from NZ could lead to similar values, but it would be more difficult to derive similar milk revenues because costs, such as transportation, need to be added. However, these are fixed costs and hence do not influence the variability of the milk price.

To assess the investment decision, we applied the general form of Equation 1 for our underlying investment decision and calculated the NPV for a given milking technology $m$ as follows:

$$
\begin{aligned}
& N P V_{m}=-I N V_{m, t=0}+\sum_{t=1}^{T}\left[\frac{M R_{m} \cdot q_{m}}{(1+i+v)^{t}}\right] \\
& -\sum_{t=1}^{T}\left[\frac{\text { material }_{m, t}+\text { labor }_{m, t}}{(1+i)^{t}}\right]+\frac{\text { salv }_{m, T}}{(1+i)^{T}} .
\end{aligned}
$$

We multiplied the milk revenue $(M R)$ by the milk output $q$ and discounted using the RADR for risk-averse

Table 1. Assumptions and descriptions of fixed parameters for the net present value calculations for the

\begin{tabular}{|c|c|c|c|}
\hline \multirow[b]{2}{*}{ Variable } & \multicolumn{2}{|c|}{ System } & \multirow[b]{2}{*}{ Source } \\
\hline & AMS & Parlor & \\
\hline Cows (no.) & 60 & 60 & \\
\hline Milk revenue (ct. $/ \mathrm{kg}$ of milk) ${ }^{2}$ & 31.78 & 32.35 & Steeneveld et al. (2012) \\
\hline Labor costs (ct. $/ \mathrm{kg}$ of milk) & 10.30 & 10.72 & Steeneveld et al. (2012) \\
\hline Material costs (ct./kg of milk) & 17.17 & 16.99 & Steeneveld et al. (2012) \\
\hline Milk yield (kg/cow) & 8,297 & 8,111 & Steeneveld et al. (2012) \\
\hline Investment costs $(€)$ & 100,000 & 43,179 & Bijl et al. (2007) \\
\hline Salvage value (\% of initial investment) & 2.50 & 2.50 & Dijkhuizen et al. (1997) \\
\hline Risk-free interest rate (\%) & 5 & 5 & Bijl et al. (2007) \\
\hline Useful lifetime (yr) & 15 & 15 & Hyde et al. (2003) \\
\hline \multicolumn{4}{|c|}{$\begin{array}{l}{ }^{1} \text { Compared with Steeneveld et al. (2012), we decreased milk revenue by } 20 \% \text {. It is often assumed that the milk } \\
\text { price will decrease by } 20 \% \text { after dairy quota abolition (Henry de Frahan et al., 2011). Comparing the influ- } \\
\text { ence of milk price volatility in terms of price changes after dairy quota abolition, we also consider a sensitivity } \\
\text { analysis with a } 15 \text { and } 30 \% \text { decrease. } \\
{ }^{2} \text { ct. = euro-cent. }\end{array}$} \\
\hline
\end{tabular}
investment decision between automatic milking systems (AMS) and parlor systems ${ }^{1}$ 
dairy farmers. Furthermore, we subtracted the investment costs of the milking system (INV) and considered the salvage value (salv) after the end of $T$ as certain because the focus was on the risk of milk price volatility. In addition, we discounted costs for materials and labor with the risk-free interest rate $i$ and subtracted these. The calculation was done assuming the RADR before as well as after dairy quota abolition. For the price level after dairy quota abolition, we assumed a price reduction of $20 \%$ for both calculations (Henry de Frahan et al., 2011).

\section{RESULTS AND DISCUSSION}

\section{RADR}

In Figure 1a, the risk-loaded variable $v$ is graphed for the German milk price series and various levels of risk aversion. In comparison with the results in Figure 1a, the results of the RADR under NZ prices in Figure 1b show distinctive differences in the development of the curves over time. For instance, the risk-loaded value $v$ for highly risk-averse dairy farmers is even greater than $5 \%$ in the first years and declines to below $2 \%$ after 10 yr. In Figure 1a, the value of the variable is relatively low in comparison with Figure 1b, even for extremely risk-averse dairy farmers. This illustrates the relative stability of prices under the quota system, as Jongeneel et al. (2010) also noted.

In discussing the results of the RADR calculation after quota abolition, it is also important to reflect on the approximation of the future EU milk price volatility. We approximated the milk prices in the EU after quota abolition with a milk price series from NZ. This might be reasonable because NZ is completely liberalized and has no quota regimen. The higher export rate of NZ reflects world market conditions (FAO, 2015), which might affect the European market as well. First, Fousekis et al. (2017) concluded that a strong price relationship between Oceanian and European skim milk powder markets already existed before quota abolition. Thus, there is already an interlinkage between these markets. Second, this interlinkage might become even stronger if the EU increases milk production after dairy quota abolition and, hence, the rate of exporting dairy products increases. According to this, the existing competition between the EU and NZ for export markets in China and Southeast Asia might increase after dairy quota abolition, and we suggest that this will strongly determine the milk prices in the EU. Therefore, we argue that it is reasonable to approximate the milk price volatility after the European milk quota abolition with a milk price series from NZ.
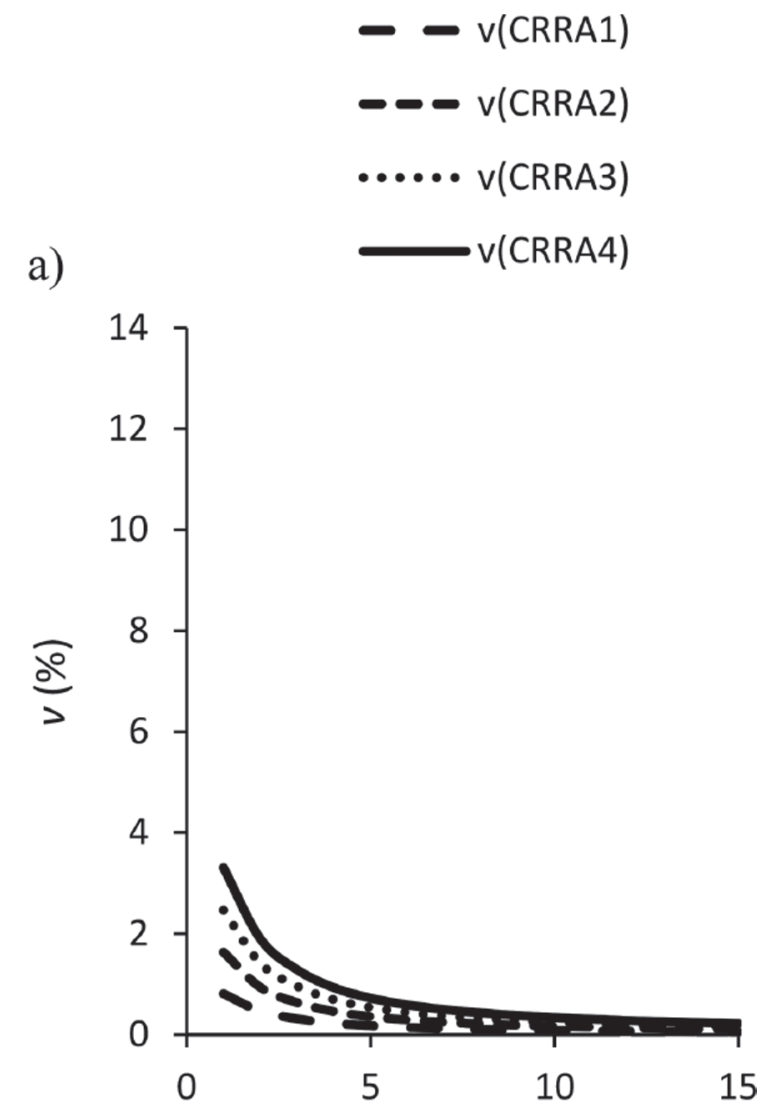

b)

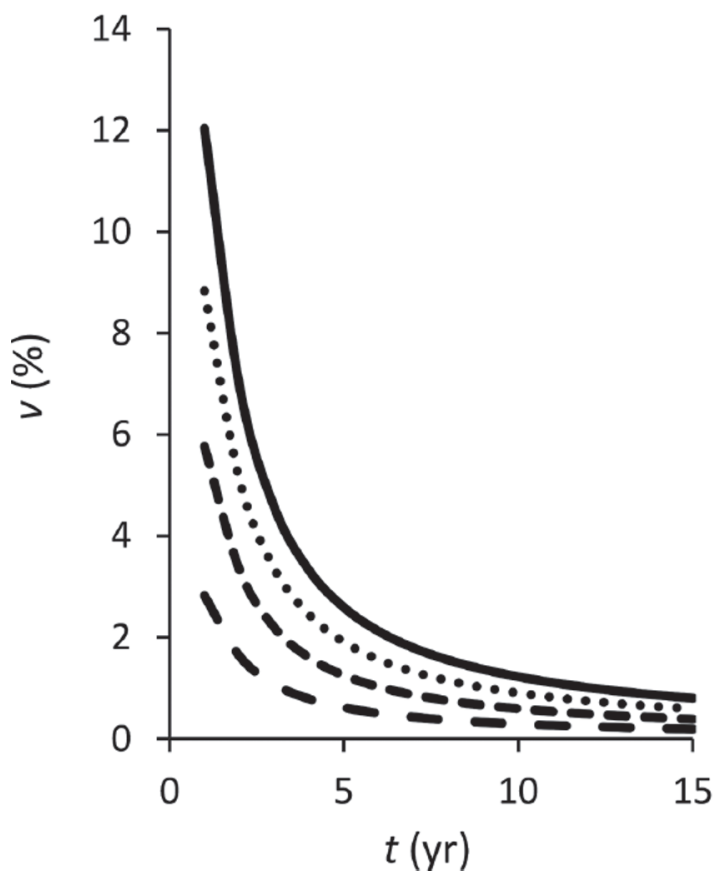

Figure 1. The risk-loading variable $v$ of the risk-adjusted discount rate for the milk price series of (a) Germany and (b) New Zealand. A constant relative risk aversion (CRRA) of 1 implies weak risk aversion, and a CRRA of 4 denotes extreme risk aversion. Adding $v$ to the riskfree interest rate $i$ leads to the risk-adjusted discount rate. 


\section{Investment Decisions After Dairy Quota Abolition}

To demonstrate how price volatility after milk quota abolition can influence results of investment decisions, we calculated the NPV for both a parlor system and an AMS on the dairy farm level. Based on the parameters from Table 1, we performed the analysis for a risk-neutral (CRRA of 0) and a modestly risk-averse (CRRA of 2) dairy farmer (Gardebroek, 2006; El Benni and Finger, 2013) as well as using the prices from Germany and NZ.

In Table 2, we compare the influence of price volatility with the influence of changing price levels. In the left part of the table, we have the results of the NPV calculation if we assume risk neutrality. The decision maker is risk neutral and hence not willing to pay a risk premium to drop the exposure to the risk of price volatility. To assess the profitability of the investment decision, the risk-neutral decision maker only considers changes of price levels after dairy quota abolition.

Focusing on the same calculation but assuming a modest level of risk aversion, the results in the right part of the table show a considerable change of the profitability for the investment decision. Assuming a price reduction of $20 \%$ and considering the milk price volatility before quota abolition, the NPV for the parlor system is €191,723 but the risk-averse decision maker expects a profitability of $€ 167,805$. For the AMS investment, the same calculations lead to €132,702 for risk-neutral dairy farmers and $€ 99,570$ for risk-averse dairy farmers. This gap increases if we assume the expected higher level of price volatility after dairy quota abolition. For the parlor investment, the profitability differs from $€ 191,723$ for the risk neutral decision maker to $€ 100,189$ for the risk-averse decision maker. For the AMS investment, the same calculations lead to $€ 132,702$ for risk-neutral dairy farmers and €31,635 for risk-averse dairy farmers. In other words, neglecting price volatility and the risk-averse attitude of the decision maker is rather similar to a $5 \%$ price change after dairy quota abolition. For instance, assuming a price reduction of $15 \%$ and investing in a parlor, the risk-neutral decision maker expects a profitability of $€ 293,963$, whereas a price reduction of $20 \%$ would lead to $€ 191,825$. Investing in AMS, it looks similar and maintains the influence of milk price volatility after dairy quota abolition for risk-averse dairy farmers.

According to input cost risk, we focused on feed price, which reflect the greatest level of costs on the input side (Wolf, 2010). Following Wolf (2010), one might conjecture that feed price changes in the United States are not an additional risk for profitability because milk price and feed costs are positively correlated and therefore the margin between milk price and feed price is relatively stable. Focusing on the German market, we had access to the feed price series between 2007 and 2014 with monthly observations (AMI, 2018) and found a positive correlation of 0.6 for the milk price and the feed price. One might conjecture from this that the feed price is not a high additional risk for German dairy farmers because feed price and milk price are moving in tendency in a similar direction. However, Wolf (2010) stressed that the milk-to-feed price ratio becomes a poor measure of profitability when a considerable change in the pattern of one or both price series occurs. According to this finding, we argue that the European dairy quota abolition is a considerable change that influences the milk price series and might distort the correlation between milk price and feed price. To model this relationship after dairy quota abolition for the underlying investment decision, we cannot refer to an additional price series to approximate feed price volatility after dairy quota abolition. Furthermore, the exposure to feed price varies with the level of specialization. For

Table 2. Sensitivity analysis of the profitability $(€)$ calculation for the investment decision between an automatic milking system (AMS) and a parlor system ${ }^{1}$

\begin{tabular}{|c|c|c|c|c|c|c|}
\hline \multirow{3}{*}{$\begin{array}{l}\text { Milk price } \\
\text { reduction }(\%)\end{array}$} & \multicolumn{2}{|c|}{ CRRA 0} & \multicolumn{4}{|c|}{ CRRA 2} \\
\hline & \multicolumn{2}{|c|}{ Before and after quota } & \multicolumn{2}{|c|}{ Before quota ${ }^{2}$} & \multicolumn{2}{|c|}{ After quota $^{3}$} \\
\hline & AMS & Parlor & AMS & Parlor & AMS & Parlor \\
\hline 15 & 226,322 & 293,963 & 200,682 & 268,442 & 128,501 & 196,601 \\
\hline 20 & 132,702 & 191,723 & 99,570 & 167,805 & 31,635 & 100,094 \\
\hline 30 & $-81,539$ & $-12,453$ & $-102,654$ & $-33,469$ & $-162,098$ & $-92,633$ \\
\hline
\end{tabular}

${ }^{1} \mathrm{~A}$ constant relative risk aversion (CRRA) of 2 implies that the decision maker is rather risk averse (Hardaker et al., 2004). Risk-neutral decision makers are not willing to pay a risk premium to get rid of the exposure to milk price volatility.

${ }^{2}$ Profitability concerning milk price volatility before dairy quota abolition.

${ }^{3}$ Profitability assuming milk price volatility after dairy quota abolition. 
Table 3. Sensitivity analysis concerning the influence of feed cost variation on the profitability $(€)$ calculation for the investment decision between an automatic milking system (AMS) and a parlor system ${ }^{1}$

\begin{tabular}{|c|c|c|c|c|c|c|}
\hline \multirow{3}{*}{$\begin{array}{l}\text { Change of risk } \\
\text { premium }(\%)\end{array}$} & \multicolumn{2}{|c|}{ CRRA 0} & \multicolumn{4}{|c|}{ CRRA 2} \\
\hline & \multicolumn{2}{|c|}{ Before and after quota } & \multicolumn{2}{|c|}{ Before quota $^{2}$} & \multicolumn{2}{|c|}{ After quota $^{3}$} \\
\hline & AMS & Parlor & AMS & Parlor & AMS & Parlor \\
\hline-30 & \multirow{5}{*}{132,702} & \multirow{5}{*}{191,825} & 92,329 & 160,599 & 4,014 & 72,699 \\
\hline-15 & & & 95,949 & 164,202 & 17,825 & 86,444 \\
\hline 0 & & & 99,570 & 167,805 & 31,635 & 100,189 \\
\hline 15 & & & 103,189 & 171,408 & 45,445 & 113,935 \\
\hline 30 & & & 106,809 & 175,011 & 59,255 & 127,680 \\
\hline \multicolumn{7}{|c|}{$\begin{array}{l}{ }^{1} \text { A constant relative risk aversion (CRRA) of } 2 \text { implies that the decision maker is rather risk averse (Hardaker } \\
\text { et al., 2004). Risk-neutral decision makers are not willing to pay a risk premium to get rid of the exposure to } \\
\text { milk price volatility. }\end{array}$} \\
\hline \multicolumn{7}{|c|}{$\begin{array}{l}{ }^{2} \text { Profitability concerning milk price volatility before dairy quota abolition and approximating the influence } \\
\text { feed cost variation. }\end{array}$} \\
\hline
\end{tabular}

instance, the income of an extensive pasture-based system might be less dependent on feed price changes than a high-yielding milking system, which intensively feeds concentrates.

To account for this risk, we extended the suggested sensitivity analysis and assume that feed cost variation either adds or reduces the existing risk premium (see Table 3). We assume a 15 and $30 \%$ increase as well as a 15 and $30 \%$ decrease of the risk premium because it is not clear how and to what extent the input price influences the milk price risk of dairy farmers.

Following the results of the sensitivity analysis in Table 3, profitability of investment on dairy farms differs considerably if the feed cost variation is able to influence the risk premium of the milk price volatility. For instance, comparing the values across columns, the profitability differs by approximately $€ 50,000$ for the parlor investment as well as for the AMS. Although our results follow approximations of future price volatilities, we might conclude that the increasing milk price volatility and the possible influence of feed price variation might become a crucial attribute to assess investment decisions after dairy quota abolition.

Discussing the results, we provided the framework to approximate and implement milk price volatility after dairy quota abolition. To apply our findings, we mainly followed the outcome of Steeneveld et al. (2012), but previous studies show that the outcome of the investment calculation might vary depending on the assumptions of the underlying variables (Dijkhuizen et al., 1997; Hyde et al., 2003; Rotz et al., 2003). For instance, previous studies assumed higher feed costs for AMS because cows were milked more often, which leads to higher milk yields (Dijkhuizen et al., 1997; Hyde et al., 2003). Furthermore, herd size might matter as well and has to be appropriately matched to the capacity of the milking system. For instance, for herds with more than 120 cows and following Rotz et al. (2003), AMS had a lower net return than a parlor system because the initial investment per animal was higher. In contrast, labor conditions and availability of skilled labor could be reasons to invest in AMS in the future (Salfer et al., 2017). For instance, Salfer et al. (2017) stressed that AMS investment could be beneficial because the availability of skilled labor might decrease and wages could increase in the future. Accordingly, Rodenburg (2017) showed that installing AMS might provide a more desirable lifestyle and that even larger farms might benefit from reducing labor. Beyond profitability, Hogeveen et al. (2004) indicated that labor flexibility and decreasing heavy labor were the main reason for Dutch dairy farmers to invest in AMS. Hence, the availability of labor and the lifestyle of dairy farmers might play a role to invest in AMS.

Second, milk and livestock production faces an uncertain future development (Thornton, 2010; Havlík et al., 2014). Future outlooks to improve the sustainability of the food system argue that the consumption of milk and meat need to be reduced to diminish climate change. These are relatively vague future risks, but they could lead to further obligations for dairy farmers that might influence the profitability of such investments.

Finally, the main focus of the underlying calculations was related to the influence of milk price volatility on investment decisions. Implementing feed price risk we were only able to conduct a sensitivity analysis, but further research could quantify the relationship more thoroughly and assess the influence of the correlation between milk prices and feed price dependent on the intensity of the production system and risk attitude. 
Furthermore, we assumed that the dairy farmer has to invest in either an AMS or a parlor system. However, if managerial flexibility exists for this investment decision, future research could determine how to facilitate the implementation of the time-varying RADR with real option approach.

\section{CONCLUSIONS}

We calculated the RADR for risk-averse dairy farmers based on expected changes in milk price volatility before and after quota abolition. Following expected utility approaches, this procedure allows adjustment of the RADR for the level of milk price volatility and the risk attitude of a decision maker. We approximated the milk price volatility after dairy quota abolition with a time series from NZ and applied the RADR with different levels of risk aversion for an investment decision between 2 different milking technologies. For risk-averse dairy farmers, the increasing milk price volatility affects the profitability of investments considerably. However, our results show that even if milk price volatility increases and dairy farmers are modestly risk averse, it is still reasonable for an average German dairy farmer to invest in a parlor system, and this is preferable to investing in an AMS. To asses investment analysis after dairy quota abolition, we recommend the use of the RADR for integrating milk price volatility and the level of risk aversion for investment decisions at the dairy farm level. Thus, we predict that it might become useful to consider the increasing influence of milk price volatility for financing investments after dairy quota abolition.

\section{ACKNOWLEDGMENTS}

The authors thank 2 anonymous referees for helpful comments and suggestions as well as the Dutch agricultural and horticultural organization LTO for providing the milk price series and the German AMI for providing the feed price series.

\section{REFERENCES}

AMI (Agrarmarkt Informations-Gesellschaft). 2018. AMI Preise für Futtermittel. Accessed Feb. 19, 2018. https://www.ami-informiert .de/ami-onlinedienste/serviceportal-forschung-lehre/futtermittel/ marktdaten-download.html.

Assefa, T. T., M. P. Meuwissen, and A. G. Oude Lansink. 2017. Price risk perceptions and management strategies in selected European food supply chains: An exploratory approach. Wagen. J. Life Sci. 80:15-26. https://doi.org/10.1016/j.njas.2016.11.002.

Bijl, R., S. R. Kooistra, and H. Hogeveen. 2007. The profitability of automatic milking on Dutch dairy farms. J. Dairy Sci. 90:239-248. https://doi.org/10.3168/jds.S0022-0302(07)72625-5.

Di Falco, S., and J. P. Chavas. 2006. Crop genetic diversity, farm productivity and the management of environmental risk in rainfed agriculture. Eur. Rev. Agric. Econ. 33:289-314. https://doi.org/10 $.1093 /$ eurrag/jbl016.

Dijkhuizen, A. A., R. B. M. Huirne, S. B. Harsh, and R. W. Gardner. 1997. Economics of robot application. Comput. Electron. Agric. 17:111-121. https://doi.org/10.1016/S0168-1699(96)01228-8.

Dixit, A. K., and R. S. Pindyck. 1994. Investment Under Uncertainty. Princeton University Press, Princeton, NJ.

El Benni, N., and R. Finger. 2013. Gross revenue risk in Swiss dairy farming. J. Dairy Sci. 96:936-948. https://doi.org/10.3168/jds $.2012-5695$.

Elliott, G., T. J. Rothenberg, and J. H. Stock. 1996. Efficient tests for an autoregressive unit root. Econometrica 64:813-836. https://doi .org/10.3386/t0130.

FAO (Food and Agriculture Organization of the United Nations). 2015. Milk and milk products-Market outlook 2015. Accessed Aug. 9, 2016. http://www.fao.org/fileadmin/templates/est/COMM _MARKETS_MONITORING/Dairy/Documents/FO_May_2015 -Dairy.pdf.

Finger, R. 2016. Assessment of uncertain returns from investment in short rotation coppice using risk adjusted discount rates. Biomass Bioenergy 85:320-326. https://doi.org/10.1016/j.biombioe.2015.12 .028 .

Fousekis, P., C. Emmanouilides, and V. Grigoriadis. 2017. Price linkages in the international skim milk powder market: Empirical evidence from nonparametric and time-varying copulas. Aust. J. Agric. Resour. Econ. 61:135-153. https://doi.org/10.1111/1467-8489 $.12147 /$ full

Frederick, S., G. Loewenstein, and T. O'Donoghue. 2002. Time discounting and time preference: A critical review. J. Econ. Lit. 40:351-401.

Gardebroek, C. 2006. Comparing risk attitudes of organic and non-organic farmers with a Bayesian random coefficient model. Eur. Rev Agric. Econ. 33:485-510. https://doi.org/10.1093/erae/jbl029.

Hardaker, J. B., R. B. M. Huirne, J. R. Anderson, and G. Lien. 2004 Coping with Risk in Agriculture. 2nd ed. CABI, Oxfordshire, UK.

Havlík, P., H. Valin, M. Herrero, M. Obersteiner, E. Schmid, M. C. Rufino, A. Mosnier, P. K. Thornton, H. Böttcher, R. T. Conant, S. Frank, S. Fritz, S. Fuss, F. Kraxner, and A. Notenbaert. 2014. Climate change mitigation through livestock system transitions. Proc. Natl. Acad. Sci. USA 111:3709-3714.

Henry de Frahan, B., A. Baudry, R. De Blander, P. Polomé, and R. Howitt. 2011. Dairy farms without quotas in Belgium: Estimation and simulation with a flexible cost function. Eur. Rev. Agric. Econ. 38:469-495. https://doi.org/10.1093/erae/jbr013.

Hogeveen, H., K. Heemskerk, and E. Mathijs. 2004. Motivations of Dutch dairy farmers to invest in an automatic milking system or a conventional milking parlour. Pages 56-61 in Automatic Milking: A Better Understanding. A. Meijering, H. Hogeveen, and C. J. A. M. de Koning, ed. Wageningen Academic Publishers, Wageningen, the Netherlands.

Hyde, J., J. W. Dunn, A. Steward, and E. R. Hollabaugh. 2007. Robots don't get sick or get paid overtime, but are they a profitable option for milking cows? Appl. Econ. Perspect. Policy 29:366-380. https://doi.org/10.1111/j.1467-9353.2007.00348.x.

Hyde, J., J. R. Stokes, and P. D. Engel. 2003. Optimal investment in an automatic milking system: An application of real options. Agr. Financ. Rev. 63:75-92. https://doi.org/10.1108/00215010380001142.

Isik, M. 2006. Implications of alternative stochastic processes for investment in agricultural technologies. Appl. Econ. Lett. 13:21-27. https://doi.org/10.1080/13504850500378205.

Jongeneel, R., S. V. Berkum, C. D. Bont, C. V. Bruchem, J. Helming, and J. Jager. 2010. European dairy policy in the years to come; Quota abolition and competitiveness. Rapport-LandbouwEconomisch Instituut 2010-017. LEI Wageningen UR, The Hague, the Netherlands.

Kim, K., and J. P. Chavas. 2003. Technological change and risk management: An application to the economics of corn production. Agric. Econ. 29:125-142. https://doi.org/10.1111/j.1574-0862.2003 .tb00152.x.

Laibson, D. 1997. Golden eggs and hyperbolic discounting. Q. J. Econ. 112:443-478. https://doi.org/10.1162/003355397555253. 
LTO Nederland. 2016. International milk price reviews. Accessed Jul. 7, 2016. http://www.milkprices.nl/.

Maart-Noelck, S. C., and O. Musshoff. 2014. Measuring the risk attitude of decision-makers: Are there differences between groups of methods and persons? Aust. J. Agric. Resour. Econ. 58:336-352. https://doi.org/10.1111/j.1467-8489.2012.00620.x.

Pratt, J. W. 1964. Risk aversion in the small and in the large. Econometrica 32:122-136. https://doi.org/10.1016/B978-0-12-214850-7 .50010-3.

Purvis, A., W. G. Boggess, C. B. Moss, and J. Holt. 1995. Technology adoption decisions under irreversibility and uncertainty: An ex ante approach. Am. J. Agric. Econ. 77:541-551. https://doi.org/ $10.2307 / 1243223$.

Rodenburg, J. 2017. Robotic milking: Technology, farm design, and effects on work flow. J. Dairy Sci. 100:7729-7738. https://doi.org/ $10.3168 /$ jds.2016-11715.

Rotz, C. A., C. U. Coiner, and K. J. Soder. 2003. Automatic milking systems, farm size, and milk production. J. Dairy Sci. 86:41674177. https://doi.org/10.3168/jds.S0022-0302(03)74032-6.

Salfer, J. A., K. Minegishi, W. Lazarus, E. Berning, and M. I. Endres. 2017. Finances and returns for robotic dairies. J. Dairy Sci. 100:7739-7749. https://doi.org/10.3168/jds.2016-11976.

Scharner, M., S. Poechtrager, and M. Larcher. 2016. Risk attitude and risk perception of dairy farmers in Austria. German J. Agric. Econ. 65:262-273.

Shortall, J., L. Shalloo, C. Foley, R. D. Sleator, and B. O'Brien. 2016. Investment appraisal of automatic milking and conventional milk- ing technologies in a pasture-based dairy system. J. Dairy Sci. 99:7700-7713. https://doi.org/10.3168/jds.2016-11256.

Statistisches Bundesamt. 2016. Trotz sehr niedriger Milchpreise nur leichter Rückgang bei Milchkühen. Accessed Aug. 10, 2016. https://www.destatis.de/DE/ZahlenFakten/ Wirtschaftsbereiche/LandForstwirtschaftFischerei/ TiereundtierischeErzeugung/AktuellRinder.html;jsessionid= FC21E25F311B9CA14D8D705D59AE2770.cae2.

Steeneveld, W., L. W. Tauer, H. Hogeveen, and A. Oude Lansink. 2012. Comparing technical efficiency of farms with an automatic milking system and a conventional milking system. J. Dairy Sci. 95:7391-7398. https://doi.org/10.3168/jds.2012-5482.

Tauer, L. W. 2002. Estimating risk-adjusted interest rates for dairy farms. Agr. Financ. Rev. 62:59-68. https://doi.org/10.1108/ 00214880280001129 .

Tauer, L. W. 2006. When to get in and out of dairy farming: A real option analysis. Agric. Resour. Econ. Rev. 35:339-347. https://doi .org/10.1017/S1068280500006778.

Thornton, P. K. 2010. Livestock production: Recent trends, future prospects. Philos. Trans. R. Soc. Lond. B Biol. Sci. 365:2853-2867.

Vasicek, O. 1977. An equilibrium characterization of the term structure. J. Financ. Econ. 5:177-188. https://doi.org/10.1016/0304 $-405 X(77) 90016-2$.

Wolf, C. A. 2010. Understanding the milk-to-feed price ratio as a proxy for dairy farm profitability. J. Dairy Sci. 93:4942-4948. https://doi .org/10.3168/jds.2009-2998. 